\title{
The Proceedings of the International Conference
}

on Creationism

Volume 8

Print Reference: Pages 553-566

Article 46

2018

\section{Locating the Flood/post-Flood Boundary Using the Relative Dating of the Weathering of Ore Deposits}

Andrew A. Snelling

Answers in Genesis

Follow this and additional works at: https://digitalcommons.cedarville.edu/icc_proceedings

DigitalCommons@Cedarville provides a publication platform for fully open access journals, which means that all articles are available on the Internet to all users immediately upon publication. However, the opinions and sentiments expressed by the authors of articles published in our journals do not necessarily indicate the endorsement or reflect the views of DigitalCommons@Cedarville, the Centennial Library, or Cedarville University and its employees. The authors are solely responsible for the content of their work. Please address questions to dc@cedarville.edu.

Browse the contents of this volume of The Proceedings of the International Conference on Creationism.

\section{Recommended Citation}

Snelling, A.A. 2018. Locating the Flood/post-Flood boundary using the relative dating of the weathering of ore deposits. In Proceedings of the Eighth International Conference on Creationism, ed. J.H. Whitmore, pp. 553-566. Pittsburgh, Pennsylvania: Creation Science Fellowship. 


\title{
LOCATING THE FLOOD/POST-FLOOD BOUNDARY USING THE RELATIVE DATING OF THE WEATHERING OF ORE DEPOSITS
}

Andrew A. Snelling, Answers in Genesis, PO Box 510, Hebron, KY 41048 USA, asnelling@answersingenesis.org

\begin{abstract}
Erosion at the end of and after the Flood exposed the tops of primary ore deposits to subsequent weathering and the formation of supergene minerals. The ${ }^{40} \mathrm{Ar} /{ }^{39} \mathrm{Ar}$ and $(\mathrm{U}-\mathrm{Th}) / \mathrm{He}$ radioisotope methods applied to these supergene minerals provide the dates for when these minerals formed. But given the documented problems with the radioisotope methods, they can only provide at best relative dates. When the Flood waters retreated, the ground surface was dry, but extra time was needed to allow the water table to drop, soil to form and plants to grow before Noah stepped off the Ark, which marked the end of the Flood event. The weathering front then progressed downwards during the early post-Flood decades for supergene minerals to start forming. Residual post-Flood catastrophism may have involved mountains still rising and ore deposits still forming, such as the porphyry copper deposits associated with granite intrusions as the Andes continued to rise. Erosion exposed those later-formed ore deposits to subsequent weathering to produce supergene minerals well into the early post-Flood era. Thus, the relative ages of the supergene iron oxides, and potassium-bearing sulfates and manganese oxides produced span the whole Cenozoic. It is proposed that relative dates for the first formation of supergene minerals can possibly be used as a criterion for determining the placement of the Flood/post-Flood boundary at the K-Pg boundary with a relative age of $66 \mathrm{Ma}$. The few slightly earlier relative ages likely resulted from weathering that commenced before the Flood event ended, though deep weathering would have required decades. The spread of relative ages through the Cenozoic thus represents the progressive formation of supergene minerals as primary ore deposits emplaced during, and maybe after, the Flood were subsequently exposed to weathering by residual catastrophism. Continuing investigation of this criterion for placement of the Flood/post-Flood boundary seems warranted.
\end{abstract}

\section{KEY WORDS}

Flood/post-Flood boundary, ore deposits, weathering, erosion, supergene minerals, ${ }^{40} \mathrm{Ar}{ }^{\beta 9} \mathrm{Ar}$ dating, (U-Th)/He dating, relative dating, K-Pg boundary

\section{INTRODUCTION}

The location of the Flood/post-Flood boundary in the geologic record has long been a contentious issue debated in the creationist literature (Snelling 2014a, c). However, it is crucial for the coherency and advancement of the Creation-Flood model of earth history for this issue to be resolved definitively. There are primarily two contenders which have been proposed for this boundary's location.

The first proposed location is at the Cretaceous/Paleogene $(\mathrm{K} /$ $\mathrm{Pg}$ ) boundary (formerly known as the Cretaceous/Tertiary or K/T boundary) (Austin et al 1994). Above this boundary are lineages of mammal fossils that link extant mammals to their fossilized within-kind ancestors, even within the same geographic regions (Ross 2012, 2014a, b; Snelling 2014c; Whitmore and Wise 2008). Opponents of this view have failed to explain in a consistent and coherent scenario why both the Cenozoic fossil and related extant mammals are found in the same geographic regions, unless all belong to the same post-Flood population lineages (Oard 2007, 2010c, 2013a; Walker 2014a, b). For example, if Miocene fossil kangaroos found only in Australia are pre-Flood kangaroos buried by the Flood, then it is highly fortuitous that the related living kangaroos are also only found in Australia. However, Clarey (2016) raised the question of how large mammals could disperse in a post-Flood world prior to the Ice Age land bridges.
The alternate proposed location is at or very near the Pliocene/ Pleistocene boundary (or what used to be called the Tertiary/ Quaternary boundary). Several arguments have been advanced. Some proponents argue that there is too large a volume of Cenozoic sedimentary and volcanic rocks, which would make the post-Flood world too catastrophic, when instead they maintain those sediments and volcanics required Flood rate and scale geologic processes well beyond local catastrophes (Clarey 2015a, c, 2017; Holt 1996; Oard 2010b, 2011, 2013a). Others point to examples of large-scale Cenozoic erosion and its products that they claim had to happen when the Flood waters were receding in order to explain the scale of erosion that is observed (Holt 1996; Oard 2004, 2007, 2013a, b).

Whitmore and Garner (2008) attempted to develop a list of criteria which can be used to delineate the location of this boundary in strata sequences. Included in their list was the category "true paleosols". They reasoned that since the Flood involved the rapid accumulation of sediments without the passage of long periods between the deposition of individual layers, we would not expect the development of true soil horizons during the Flood. On the other hand, after the Flood weathered horizons and paleosols would be expected to become more abundant due to the extended time for their development. Nevertheless, they ranked this as only a tertiary criterion, because true paleosols are difficult to diagnose and they 
could also be present in pre-Flood strata sequences.

However, the supergene weathering of many ore deposits at today's earth surface may still offer an additional criterion for determining the location of the Flood/post-Flood boundary in the geologic record. This is because other criteria can be used to establish that the primary ore deposits were indeed formed during the Flood or even pre-Flood. For example, most porphyry copper deposits are hosted by granite plutons which intrude into fossilbearing, Flood-deposited sedimentary layers. On the other hand, Precambrian banded iron formations (BIFs) were largely formed before the Flood and may even date back to the Creation Week (Snelling 2009) but were only exposed at the earth's surface as a result of the erosion at the end of the Flood as the waters retreated. Furthermore, lateritic iron and manganese deposits were deposited as sedimentary layers on top of or between fossil-bearing, Flooddeposited sedimentary layers. Of course, some of these porphyry copper and lateritic iron and manganese deposits may also have formed in the first decades after the Flood due to the declining residual catastrophism.

Some consideration needs to also be given to the chronology of the Flood, and especially the timing and actions of the Flood waters when they retreated. This is highly relevant to the question of when the primary ore deposits were exposed by erosion to weathering, which then initiated the formation of the supergene minerals. For example, the granite plutons hosting the porphyry copper deposits were intruded some $2-5 \mathrm{~km}$ below the ground surface at that time, so that $2-5 \mathrm{~km}$ of overlying host rocks had to first be eroded away to expose the primary copper ore to weathering and formation of the supergene minerals that have been radioisotope dated. The timing of this weathering relative to the end of the Flood is crucial to considering whether the radioisotope ages derived for the supergene minerals can pinpoint where the Flood/post-Flood boundary should be placed in the geologic record.

\section{SUPERGENE WEATHERING OF ORE DEPOSITS}

Supergene metallic ore deposits form when common rock types or deeply buried primary metallic ore bodies are exposed at or within $1000 \mathrm{~m}$ of the earth's surface. It is necessary to avoid confusion here by defining the term supergene. Supergene is "said of a mineral deposit or enrichment formed near the surface, commonly by descending solutions" (Neuendorf et al. 2005, p.645). Thus, supergene alteration of primary ore deposits, which is due to the downward passage of weathering and oxygenated groundwaters and occurs at in situ ground temperatures, should not be confused with hypogene or hydrothermal alteration of primary ore deposits. Hypogene is "said of a mineral deposit formed by ascending solutions" (Neuendorf et al. 2005, p.315). Hydrothermal alteration generally produces a different set of minerals from those produced by supergene alteration. And hydrothermal alteration usually occurs at depths $>1 \mathrm{~km}$, whereas supergene alteration occurs at $<1$ $\mathrm{km}$ depth and is related to groundwater fluctuations and oxygen in the atmosphere penetrating downwards from the land surface.

Rocks and ore deposits that were formed at high temperatures and high pressures when exposed at and near the earth's surface have their equilibrium disturbed. This causes their mineral constituents to react and undergo transformations so as to adjust to the new lower temperatures, pressures, and higher oxygen concentrations and moisture conditions. They undergo chemical weathering, which promotes the oxidation, dissolution, remobilization, reprecipitation, and re-concentration of metals of economic interest.

Recurrent dissolution, transport, and re-deposition of metals through time has created a chemically stratified weathering profile (Reich and Vasconcelos 2015) that contains a comprehensive record of these chemical reactions which have occurred at the earth's surface. Today's rates of these reactions are invariably climate-dependent, reflecting ambient temperature, availability of liquid water (involving rainfall intensity and seasonality), evapotranspiration rates, and biological and microbiological activity (Vasconcelos 1999a).

The phenomenon known as supergene enrichment refers to the secondary, in situ, accumulation of metals (for example, $\mathrm{Cu}, \mathrm{Zn}$, $\mathrm{Ag}, \mathrm{Au}, \mathrm{Ni}$, or $\mathrm{U}$ ) as a result of three essential processes:

1)The electrochemical oxidation of primary sulfides, oxides or native metals (for example, native copper $\mathrm{Cu}^{0}$ to $\mathrm{Cu}^{2+}$ );

2)The transport of the released metals as soluble metal species (for example, $\mathrm{CuSO}_{4}{ }^{0}, \mathrm{AuCl}_{4}{ }^{\mathrm{l}}$ ); and

3)The reprecipitation of the metals by reduction (for example, $\mathrm{Cu}^{2+}$ to native copper $\mathrm{Cu}^{0}$ ), by supersaturation (for example, $\mathrm{Mg}^{2+}$ in magnesite deposits), or by cation-exchange (for example, $\mathrm{Ni}^{2+}$ exchange for $\mathrm{Mg}^{2+}$ in smectite- or serpentine-group minerals).

In particular, oxidation processes leading to mineral leaching are commonly catalyzed by specialized Fe- and S-oxidizing bacteria. Oxidation processes are also active in the surficial vadose zone and the capillary fringe above the water table. Leaching processes also respond to changes in physicochemical properties, such as the partial pressure of oxygen $\left(p \mathrm{O}_{2}\right)$, and its effect on the redox potential (Eh), as well as the activity of $\mathrm{H}^{+}$of descending aqueous solutions (Reich et al. 2009; Sillitoe 2005).

Weathering profiles hosting supergene ore deposits may extend down to $1000 \mathrm{~m}$ below the surface, but they are mostly inaccessible to scientific investigation. When these systems are drilled for their mineral potential and eventually exposed by open-pit mining operations - some open pits may be 5-6 km wide and more than $1 \mathrm{~km}$ deep - they provide access to paleoclimatic records that are otherwise unavailable.

Minerals found in supergene ore deposits record information about chemical reactions and geochemical (and paleoclimatic) conditions prevailing during the formation of the deposits. Detailed descriptions of these chemical reactions which form the main minerals produced by supergene weathering of ore deposits are provided in the Appendix.

\section{DATING OF SUPERGENE MINERALS}

Supergene metal deposits host a comprehensive record of climatedriven geochemical reactions that may span the entire Cenozoic. Products of these reactions can be dated by a variety of radiogenic isotopic methods, such as ${ }^{40} \mathrm{Ar} /{ }^{39} \mathrm{Ar}$, (U-Th)/He, U-Pb, and U-series. High spatial resolution methods have distinct advantages when dating minerals from soils and weathering profiles that contain complex assemblages of intimately intergrown minerals precipitated at distinctly different times. The most commonly 
used geochronological methods for weathering geochronology are ${ }^{40} \mathrm{Ar} /{ }^{39} \mathrm{Ar}$ laser incremental heating analysis of $\mathrm{K}$-bearing supergene minerals (particularly the hollandite-group $\mathrm{K}$-Mn-oxides and alunite group sulfates) and (U-Th)/He analysis of supergene oxides and hydroxides (hematite and goethite).

Some of the minerals found in the supergene weathering zones of ore deposits can be dated using the ${ }^{40} \mathrm{Ar} /{ }^{39} \mathrm{Ar}$ radioisotope method (Vasconcelos 1999a, b). It could be argued that method is unreliable and so cannot provide absolute dates (Snelling 2016a, 2017a). However, when it is carefully used it can still provide relative dates, anchored to the biblical parameters for subdividing and dating the rock record (Vardiman, Snelling and Chaffin 2005). So supergene weathering minerals such as alunite $\left[\mathrm{KAl}_{3}\left(\mathrm{SO}_{4}\right)_{2}(\mathrm{OH})_{6}\right]$, jarosite $\left[\mathrm{KFe}_{3}^{3+}(\mathrm{OH})_{6}\left(\mathrm{SO}_{4}\right)_{2}\right]$, and hollandite $\left[\mathrm{Ba}, \mathrm{K}\left(\mathrm{Mn}_{6}^{4+}{ }_{6} \mathrm{Mn}^{3+}{ }_{2}\right) \mathrm{O}_{16}\right]$ have proven to be good candidates for ${ }^{40} \mathrm{Ar} /{ }^{39} \mathrm{Ar}$ dating of the time they formed. That potentially becomes the relative times these minerals formed after the Flood waters receded and the land was exposed to weathering.

The ${ }^{40} \mathrm{Ar} /{ }^{39} \mathrm{Ar}$ method is most widely applied because many minerals precipitated by weathering reactions contain $\mathrm{K}$ (as detailed in Table 1 in the Appendix), and many of these minerals are relatively stable once formed. If these phases retain ${ }^{40} \mathrm{~K}$ and ${ }^{40} \mathrm{Ar}$ quantitatively, then nuclide abundances can be used to determine when the mineral formed (details in Vasconcelos 1999b). The analysis of a representative suite of K-bearing supergene minerals from a vertical section through a weathering profile may be used to estimate weathering rates and to infer paleoclimatic conditions (de Oliveira Carmo and Vasconcelos 2006). A probability density distribution of mineral precipitation ages identifies times in the past when climatic conditions favored mineral dissolution and reprecipitation. Chemical reactions recorded by mineral precipitation require water as a reactant; therefore, the frequency distribution of ages through time permits one to identify periods in the geological past that were relatively wet (Vasconcelos 1999a, b).

As with K-bearing minerals, the Fe-bearing goethites and hematites generated by water-rock interactions during the formation of supergene ore bodies can be dated. The decay of trace amounts of $\mathrm{U}$ and Th in goethite and hematite (Lippolt et al. 1998) results in ${ }^{4} \mathrm{He}$ by-products that can be used for dating mineral precipitation, as long as the ${ }^{4} \mathrm{He}, \mathrm{U}$, and $\mathrm{Th}$ are retained. But properly quantifying ${ }^{4} \mathrm{He}$ retention in goethite and hematite was not possible until scientists combined the (U-Th)/He and ${ }^{4} \mathrm{He} /{ }^{3} \mathrm{He}$ methods (Shuster et al. 2005; Heim et al. 2006; Monteiro et al. 2014).

The interpretation of geochronological results for samples from weathering/supergene profiles of ore deposits requires the identification of the dated reactions (Vasconcelos 1999a). For this purpose the dated mineral samples must be characterized petrographically, and the reactions must be identified from paragenetic relationships.

\section{METHODS}

Results from applying this methodology are already available in the relevant literature (Vasconcelos et al. 2015). Geochronological data was compiled from a number of studies - South American supergene copper deposits (Alpers and Brimhall 1988; Arancibia et al. 2006; Mote et al. 2001; Sillitoe and McKee 1996; Vasconcelos 1999a); South American supergene manganese deposits (de Oliveira Carmo and Vasconcelos 2006; Spier et al. 2006; Vasconcelos 1999b); other supergene manganese deposits in Africa (Beauvais et al. 2008), Australia (Dammer et al. 1999; Feng and Vasconcelos 2007; Li and Vasconcelos 2002; Vasconcelos 2002; Vasconcelos et al. 2013), China (Deng et al. 2014; Li et al. 2007), India (Bonnet et al. 2014), and Europe (Hautmann and Lippolt 2000); and supergene iron deposits in Australia (Heim et al. 2006; Vasconcelos 1999b; Vasconcelos et al. 2013), and Brazil (Monteiro et al. 2014).

The frequency of mineral precipitation, determined by dating a representative number of samples of a particular mineral collected from distinct parts of the supergene orebody, reflects times in the geological past when weathering conditions were conducive to water-rock interaction. The frequency of mineral precipitation through time permits identifying periods in the geological past when climatic conditions were most conducive to chemical weathering and supergene ore genesis.

\section{RESULTS}

The available data were compiled in three histograms in Fig. 1 according to the supergene minerals dated (Mn oxides, goethite and hematite, or alunite-jarosite) and the dating methods used $\left[{ }^{40} \mathrm{Ar} /{ }^{39} \mathrm{Ar}\right.$ or $\left.(\mathrm{U}-\mathrm{Th}) / \mathrm{He}\right]$, showing the frequencies of conventional ages in the range 0-70 Ma in $1 \mathrm{Ma}$ increments.

The distribution of these supergene minerals through time appears to help to identify periods in the geological past conducive to the dissolution and reprecipitation of ore elements in the weathering environment. Each mineral species records slightly different conditions. For example, Mn oxides record wetter conditions needed for the reduction-dissolution processes needed to dissolve and reprecipitate $\mathrm{Mn}$ oxides in the weathering environment. In contrast, the formation and preservation of supergene alunite and jarosite required relatively dry conditions after mineral precipitation, typically achieved by drawdown of the water table during a transition from humid or semi-arid to hyper-arid conditions.

\section{DISCUSSION}

There are several issues that must be carefully considered before conclusions can be drawn from these data in Fig. 1.

\section{The Usefulness of Radioisotope Ages as Relative Ages}

It is first necessary to establish that it is still potentially valid to use radioisotope ages in a relative sense, even though it is well established that there are significant problems with the radioisotope dating methods to render the resultant ages as not absolute (Faure and Mensing 2005; Snelling 2000).

All the radioisotope dating methods are ultimately calibrated against the U-Pb and Pb-Pb methods. However, Snelling (2017a) has documented from the literature the residual uncertainties in determinations of the ${ }^{238} \mathrm{U}$ and ${ }^{235} \mathrm{U}$ decay rates, especially the latter, which is somewhat dependent on the determinations of the ${ }^{238} \mathrm{U}$ decay rate. Recently, copious measurements of the ${ }^{238} \mathrm{U} /{ }^{235} \mathrm{U}$ ratio in a very wide variety of rocks, ores, minerals and meteorites has revealed that values vary widely. Indeed, the ${ }^{238} \mathrm{U} /{ }^{235} \mathrm{U}$ ratio value of the same mineral can be very different in different rocks, including zircons, which are so often used in geochronology. 


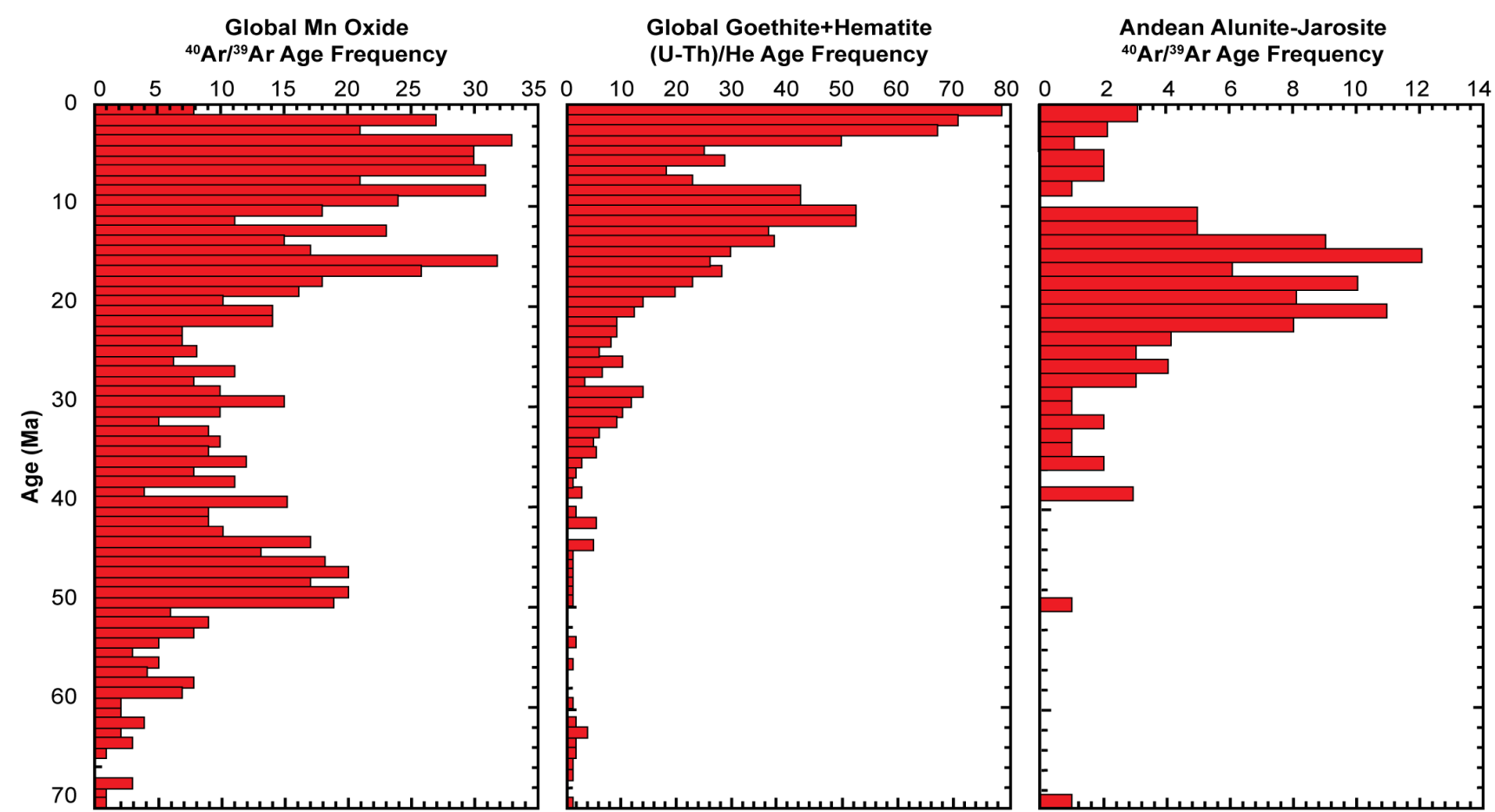

Figure 1. (a) Histogram illustrating the global distribution of ${ }^{40} \mathrm{Ar}{ }^{39} \mathrm{Ar}$ ages for supergene Mn oxides. (b) Histogram illustrating the distribution of $(\mathrm{U}-\mathrm{Th}) / \mathrm{He}$ ages for the supergene iron oxides goethite + hematite. (c) Histogram illustrating the distribution of ${ }^{40} \mathrm{Ar} /{ }^{39} \mathrm{Ar}$ ages for supergene alunite-jarosite in the Andean region. (After Vasconcelos et al. 2015.)

In any case, it was established by Vardiman et al. (2005) from five lines of evidence (discordant radioisotope ages, helium diffusion, radiohalos, fission tracks, and radiocarbon) that radioisotope decay rates may have been grossly accelerated in a catastrophic event in the recent past (namely, the Flood). Furthermore, it appeared that this accelerated decay was systematic based on the atomic weight, mode of decay, and the present decay rate of the parent radioisotopes. This hinted at the cause being due to changes in the binding forces holding the particles in the nuclei together. The key here is that the acceleration factor was systematic, which means that during the Flood the rocks would have "aged" at consistent rates around the globe as the rocks accumulated.

Thus, in a given area a rock unit that has accumulated a lot of radioisotope decay (for example, a rock unit formed in the first month of the Flood) will yield a very much older radioisotope age than a rock unit that has suffered from much less radioisotope decay (because of forming in the last month of the Flood). Furthermore, if inheritance, the initial conditions and any contamination are roughly the same in all samples from those rock units, then because the different radioisotope parents have been grossly accelerated systematically according to their atomic weights and present halflives, their apparent model and isochron ages calculated based on the present decay rates of the parent radioisotopes should essentially agree with one another.

Therefore, while the model and isochron ages will be grossly inflated and thus not be absolute ages, they will still be potentially useful as relative ages because they will be in the right order according stratigraphic relationships (Snelling 2010). This assists us in unraveling the time relationships between rock units in a given area when stratigraphic relationships are obscured by lack of outcrops due to erosion and weathering. However, it can also assist us in correlating the rock units in one area with those in another, even on another continent. After all, the radioisotope contents of rock units are simply chemical characteristics of them in much the same way as their petrologic and mineralogical characteristics, and even their fossil contents. Furthermore, the parent radioisotopes in rock units will have all suffered the same amounts of grossly accelerated decay and thus potentially give the same grossly inflated apparent model and isochron ages which will be the same relative ages.

Baumgardner (2012) has already discussed in detail the usefulness of radioisotope dates as relative ages and similarly argued that accelerated radioisotope decay rates during the Flood would systematically grossly "age" rocks in the order in which they formed in the same way globally. He reviewed the results of the RATE project (Vardiman et al. 2005), emphasizing that the existence of helium in zircons, radiohalos and fission tracks are all evidence that hundreds of millions of years' worth of radioisotope decay (as calculated from today's measured decay rates) had occurred. This amount of decay thus needs to be accounted for by grossly accelerated decay during the Flood and perhaps also during the Creation Week. And because this accelerated decay was systematic as rock units were formed progressively during those biblical events of earth history, the resultant radioisotope dates obtained can be useful as relative ages.

In the context of this study it is thus argued that after the Flood waters receded at the same time in various places on different continents, weathering of primary ore deposits would have commenced. Both the receding Flood waters and residual postFlood catastrophism would have resulted in erosion and exposure 
of primary ore deposits to weathering and supergene mineral formation over subsequent decades. The supergene minerals produced by all that weathering should thus have similar or even identical radioisotope ages, which can thus be used as identical relative ages to correlate the progressive onset of weathering at the same time at various stages on different continents in the decades after the Flood ended. This methodology, depending on how the timing of the onset of weathering is interpreted in relation to the timing of the Flood/post-Flood boundary, could help us determine the placement of that boundary in the geologic record.

\section{The Integrity and Usefulness of the Geologic Record}

There has also been considerable debate about the integrity and usefulness of the so-called geological column, as if the diagram in textbooks does not match the realities of the observable rock record (Reed and Oard 2006). Resolving misunderstandings on this issue is fundamental to building a consistent viable CreationFlood model that explains the observed details of field data of the literal physical rock record.

Creationist research has demonstrated conclusively that both individual fossil-bearing sedimentary units and megasequences of fossil-bearing sedimentary layers can be traced across continents and even between continents, precisely the evidence expected to be left behind by the global Flood cataclysm (Clarey 2015b, c, 2017; Morton 1984; Snelling 2008, 2009, 2015, 2016b, 2017b). Such transcontinental correlations of rock units underpin the construction of the geological column, ensuring its reality and integrity (Tyler and Coffin 2006). Even Oard (2010a) had to admit that "the geological column is a general Flood order". Of course, there will always be a few minor exceptions because our knowledge is incomplete, and mistakes can be made by fallible humans, but ongoing field work and research continue to add to this "big picture". Thus, in this study the integrity and usefulness of the geological column as the geologic record of earth history within the biblical chronology, especially the Flood, is accepted and utilized.

\section{The Chronology and Actions of the Retreating Flood Waters} The biblical account suggests that the Flood ended when Noah stepped off the Ark where it had landed on "the mountains of Ararat" months earlier on Day 150 (Genesis 8:4). It is generally agreed that the Flood waters were at their peak on Day 150 of the Flood, even if they had first peaked by Day 40, and they then started subsiding from Day 150 onwards (Anderson 2014; Snelling 2014a). However, the rate at which the waters receded is unclear, though the water level likely dropped slowly at first because it was only some 74 days later on Day 224 that "the tops of the mountains were seen" (Genesis 8:5), though it should also be kept in mind those mountain peaks may have risen above the waters due to the mountain-building tectonic forces of catastrophic plate tectonics (Austin et al. 1994; Snelling 2009, 2014b). And subsequently the text describes the waters being "on the face of the whole earth" (Genesis 8:9). After that, it took another 90 days until Day 314 for the waters to be "dried off the face of the earth" and "the face of the ground" to be dry (Genesis 8:13) (Snelling 2009). Even then Noah waited another 57 days until Day 371 before "the earth had dried out" sufficiently for God to instruct Noah, his family and the animals to leave the Ark, thus ending the Flood event (Genesis

\section{8:14-19) (Snelling 2009).}

It should already be evident that these considerations have implications for modeling of the geology, geophysics and paleontology of the Flood event. For example, the peaking of the Flood waters so that all flesh died has implications for when the fossil-bearing strata were deposited globally (Snelling 2014c), while the rising of the mountains has implications for when catastrophic plate collisions and isostatic uplift occurred to form today's mountain ranges (Snelling 2014b). And the timing and rate of subsiding water levels of the retreating Flood waters and their concurrent actions and motions would have implications for the erosion of the host rocks covering primary ore deposits. If erosion was too severe, not only would the cover rocks be eroded away, but the primary ore deposits as well. Radioisotope dating of the supergene minerals would provide relative dates of their formation.

Another significant stipulation should also be made here. When Noah stepped off the Ark to end the Flood event, even though the earth had dried out does not necessarily mean all residual geological and geophysical processes had ceased. Austin (1998) has documented that volcanic activity has decreased since the Flood, and Austin et al. (1994) postulated decelerating plate movements and collisions into the early post-Flood era. Thus, even ongoing volcanic and seismic activity today can be regarded as a consequence of the Flood. Furthermore, modeling post-Flood hypercanes generated by the warmer ocean waters at the end of the Flood (due to all the hot waters released from the fountains and via volcanism during the Flood), Vardiman $(2003,2012)$ demonstrated how intense storms would have dumped torrential rainfall on parts of the continents. Whitmore (2013) thus argued there was potential for resulting widespread post-Flood erosion and mass wasting processes. Therefore, while it was safe and dry for Noah to step off the Ark into the area in and near "the mountains of Ararat", in other parts of the globe residual catastrophism could still have been eroding and depositing strata, and there could have been volcanoes erupting and mountains still rising, with ocean waters still covering continental areas that today are high and dry.

\section{The Timing of Weathering and Formation of Supergene Minerals}

Before the significance of the timing of weathering to form supergene minerals can be determined, it is crucial to discuss the timing of formation of the primary (hypogene) ore deposits, especially those that were subsequently exposed to chemical weathering.

It should be first noted that not all porphyry copper deposits are of Cenozoic age. Seedorff et al. (2005, Fig. 2, p.255) document that the formation of about a third of the porphyry copper deposits conventionally date back through the Mesozoic and Paleozoic to almost $500 \mathrm{Ma}$, including in the Andean and Rockies regions. Yet it is only the very latest Mesozoic and Cenozoic porphyry copper deposits that have been subject to supergene oxidation and enrichment (Sillitoe 2005), in spite of the fact that the older porphyry copper deposits are today located within $1000 \mathrm{~m}$ of the land surface. This is clearly due to the present arid climate conditions in the Andes and the American Southwest which are conducive to supergene processes, which thus links these supergene minerals to 
the development of the current landscape.

The fact is that lateritic deposits formed by supergene weathering acting on primary ore deposits and suitable source rocks are all Cenozoic (Freyssinet et al. 2005). Even though bauxite deposits have formed from and thus sit on top of source rocks as old as the Precambrian (pre-Flood), all mined bauxite deposits are of Cenozoic age and are located in the present global subtropical and tropical belt where the climate was conducive to their formation (Freyssinet et al. 2005, Figs. 1 and 2). Similarly, all lateritic $\mathrm{Ni}$ deposits are Cenozoic and yet have formed from source rocks spanning from the Precambrian through the Phanerozoic (Freyssinet et al. 2005, Fig.11).

Other classes of primary ore deposits of all conventional ages also demonstrate that supergene weathering only affected them during the Cenozoic due to present landscape development. Volcanogenic massive sulfide deposits (Franklin et al. 2005), banded iron formations (Clout et al. 2005) and many sediment-hosted $\mathrm{Pb}-\mathrm{Zn}$ deposits (Leach et al. 2005), of all conventional ages including Precambrian and early Phanerozoic, all formed at the sediments or volcanics surface/water interfaces. Yet even though many of these deposits have distinctive syngenetic or subsequent hydrothermal alteration features, none of these ore deposits have supergene alteration associated with them that is not Cenozoic and related to the current land surface and climate. Similarly, epithermal precious and base metal deposits (Simmons et al. 2005), iron oxide coppergold deposits (Williams et al. 2005), gold deposits in metamorphic terranes (Goldfarb et al. 2005), and granite-related ore deposits (Černý et al. 2005), which are emplaced underground by hypogene processes, and whose ages span the Phanerozoic and some of the Precambrian; none of these ore deposits have any supergene alteration associated with them that is not Cenozoic and related to the current land surface and climate.

These observations are highly relevant to the objective of this study. In the conventional model it would be expected that supergene ore deposits formed at various times during the long past eons, rather than supergene ore deposits almost only being formed post-Mesozoic and related to Cenozoic to present landscape development and climate processes. Thus, while these observations are not consistent with a long-age model of earth history, they are totally consistent with only a single global Flood model of short earth history. Furthermore, these observations are relevant to their use as a criterion for determining the placement of the Flood/postFlood boundary in the geologic record.

What is then next relevant to this study is the timing of the erosion that exposed the primary ore deposits to the weathering responsible for the formation of the supergene minerals which have been radioisotope dated. Clearly, when Noah stepped off the Ark marking the end of the Flood event, large-scale erosion would have ceased over large continental regions around the globe, so the corresponding Flood/post-Flood boundary in the geologic record should be marked by a major global-scale erosion surface, onto which residual local deposits would have accumulated during the early post-Flood era. That was the rationale behind the Austin et al. (1994) choice of the Cretaceous/Paleogene (K/Pg) boundary, because they assumed the Cenozoic then represented post-Flood deposits from residual catastrophism. Localized erosion surfaces coinciding with faunal extinctions would thus have occurred during the post-Flood era. In any case, what is relevant here is that the continuing Cenozoic erosion, which Oard (2004, 2013a, b) agrees with, could have progressively exposed more ore deposits to weathering and supergene mineral formation. This is relevant to many porphyry copper deposits which formed during the Cenozoic mountain-building of the Andes, Rockies, and Alpides (Alpine-Himalayan orogenic belt) and were thus only exposed to weathering by subsequent erosion.

However, since the Flood account states the waters had "dried off the face of the earth" and "the face of the ground" was dry by Day 314 (Genesis 8:13), this could imply erosion had ceased and thus weathering of the primary ore deposits and formation of supergene minerals could have commenced in the 57 days prior to Noah stepping off the Ark and before the Flood event "officially" ended. In that scenario the radioisotope ages obtained for the formation of the supergene minerals would thus not help us date the Flood/ post-Flood boundary. However, even if the "face" or surface of the ground was dry does not guarantee that the groundwater table was not still very high and close to the surface. That could be one reason why God left Noah and his cargo still onboard the Ark for those extra 57 days, to allow the water table to drop and soils to form, as well as for plants to grow. The weathering that produces supergene minerals only occurs in the oxidizing zone above the water table (Dill 2015; Reich and Vasconcelos 2015), though it would still be wet due to evaporation of groundwater and further locally-intense rainfall. So not only did the ground surface need to be dry before weathering and supergene mineral formation could commence, but the water table had to drop down below the tops of the primary ore deposits before their oxidization could commence. Thus, the radioisotope ages obtained for the formation of the supergene minerals could still represent the relative timing of the Flood/post-Flood boundary in the geologic record.

However, could weathering and supergene mineral formation commence before the Flood ended, during the drying out phase after the Flood waters retreated? Certainly, weathering would have commenced, but it would have taken subsequent decades rather than just the last 57 days of the Flood to form the supergene minerals. This is because it takes extended time periods for the chemical weathering reactions and the lowering of the water table to penetrate deeply enough to have formed the supergene minerals at the large scale necessary to produce these supergene ore deposits. Thus, the supergene minerals are much more likely to date from the early decades after the Flood ended.

Two other considerations must also be discussed. First, the Flood involved huge volumes of water being trapped in sediments as thick strata sequences were rapidly deposited subaqueously. This water would have been oxygenated from the intense global rainfall, and acidic and warm due to the volcanic water fountains of the "great deep" and depth of burial. Then as those sediments were subsequently compacted under their own weight and due to tectonic forces, it might be expected that these warm acidic waters would rise rapidly through the strata sequences and thus potentially generate look-alike weathering profiles and supergene minerals on their way to the earth's surface. However, even though we do have 
evidence that hot acidic waters rose to the earth's surface and even produced ore deposits (for example, Franklin et al. 2005; Simmons et al. 2005), in the process they produced hydrothermal alteration that has distinctly different minerals and patterns of minerals than found in supergene ore deposits.

Second, could oxygenated surface waters have been forced hydrodynamically downward in the receding waters phase of the Flood and accomplish the same supergene alteration? It is possible that some surface water would penetrate downwards, but as noted above, the chemical weathering that produces supergene minerals only occurs in the oxidizing zone above the water table where it is drier, and air reaches down from the surface (Dill 2015; Reich and Vasconcelos 2015). Besides, as noted above, the chemical reactions that produce the supergene minerals (see the Appendix) take decades to generate ore deposits from the repeated wetting and drying of the chemical weathering profile.

\section{The Radioisotope Ages of the Supergene Minerals}

In conventional terms, the earliest dates of formation of these supergene minerals is at $70 \mathrm{Ma}$ (Fig. 1). That is just before the K-Pg boundary, currently determined at $66 \mathrm{Ma}$ (Gradstein et al. 2012). And then the frequency in numbers of mineral dates of formation per absolute date increases steadily up through the conventional Cenozoic. This frequency pattern is the same for global $\mathrm{Mn}$ oxide ${ }^{40} \mathrm{Ar} /{ }^{39} \mathrm{Ar}$ ages (Fig. 1a), global goethite + hematite (U-Th)/He ages (Fig. 1b), and Andean alunite-jarosite ${ }^{40} \mathrm{Ar} /{ }^{39} \mathrm{Ar}$ ages (Fig. 1c).

However, it is interesting that the dates of formation of alunite and jarosite in the Andes really only start around $40 \mathrm{Ma}$, and then peak in frequency around 15-20 Ma (Sillitoe and McKee 1996). This is, in part, because many of the primary (hypogene) porphyry copper deposits only formed during the mid-Cenozoic, at the time when the Andes were being built by the active plutonism and volcanism associated with the subduction of the Pacific plate under the South American plate. So, the supergene minerals then only formed subsequently from those deposits after they formed in the mid-Cenozoic. That the chemical weathering responsible for the supergene minerals was connected to the present climate and landscape development was demonstrated conclusively by the U-series dating of supergene assemblages in Chilean porphyry copper deposits by Reich et al. (2009)

It is similarly relevant and significant that the most recent set of goethite (U-Th)/He ages from the Hamersley region of northwestern Australia closely parallel the global goethite + hematite (U-Th)/ He ages in Fig. $1 b$ (Miller et al. 2017). The Hamersley province is a passive continental margin with a moderately elevated $(\sim 800 \mathrm{~m})$ interior composed of ridges and plateaus dominated by chemically resistant Archean to Paleoproterozoic banded iron formations (BIFs) and quartzites, and incised valleys consisting predominantly of shales and dolomites (Vasconcelos et al. 2013). The region has been structurally stable with little erosion for the entire Cenozoic. Much of the elevated interior is blanketed with ferruginous weathering profiles and related deposits, many of which are exposed and accessible in iron ore mines or prospects.

The prolonged process of iron mobilization and precipitation, along with later cycles of dissolution and reprecipitation of existing iron oxides, has produced a thick horizon rich in goethite with readily visible and physically separable growth zones that supposedly span many millions of years (Heim et al. 2006; Vasconcelos et al. 2013). For such samples forming at earth-surface conditions, their goethite $(\mathrm{U}-\mathrm{Th}) / \mathrm{He}$ ages are established upon mineral crystallization (Shuster et al., 2005). Goethite acquires oxygen from the water in which it forms, and after that there is no open-system behavior of the oxygen or helium in the goethite (Yapp 1991). Thus, these (U$\mathrm{Th}) / \mathrm{He}$ ages date the formation of the goethite at the water table near the surface of this Precambrian terrain (Miller et al. 2017).

Most creation geologists would regard this Precambrian terrain as pre-Flood, and likely even formed during the Creation Week (Snelling 2009). For this terrain to now be exposed in the postFlood world implies that whatever strata were deposited over it and covered it during the Flood were eroded away by the retreating Flood waters, which also eroded much of its present topography. Thus, the goethite in the present weathering profile had to form after the Flood waters retreated and the ground surface dried out, with weathering and goethite formation commencing as the Flood ended and the water table was subsequently lowered. The goethite (U-Th)/He ages span the Cenozoic from 70.5 Ma to $4.8 \mathrm{Ma}$, with intermediate ages of 68.0 Ma, 61.7 Ma, 47.3 Ma, 26.0 Ma and 8.5 Ma (Miller et al. 2017). These ages plot within the spread of ages in the histogram in Fig. $1 \mathrm{~b}$ and are also consistent with the same pattern of ${ }^{40} \mathrm{Ar} /{ }^{39} \mathrm{Ar}$ ages for Mn oxides and alunite-jarosite in Fig. $1 \mathrm{a}$ and $1 \mathrm{c}$ respectively.

Other examples further substantiate this pattern for the timing of supergene mineral formation. The supergene iron and manganese ore deposits of Minas Gerais, Brazil have developed at the present land surface from early Precambrian banded iron formations and Mn-rich sedimentary units, so the ${ }^{40} \mathrm{Ar} /{ }^{39} \mathrm{Ar}$ ages for the supergene minerals are all Cenozoic (de Oliveira Carmo and Vasconcelos 2006; Spier et al. 2006). Similarly, in Africa supergene manganese deposits have developed at the present land surface on Proterozoic (Precambrian) sedimentary units in the Katanga (De Putter et al. 2015), Kalahari (Gutzmer et al. 2012) and Burkina Faso regions (Colin et al. 2005; Beauvais et al. 2008), and the ${ }^{40} \mathrm{Ar} /{ }^{39} \mathrm{Ar}$ ages for Mn oxides are all Cenozoic, some of them being plotted in Fig. 1a.

In China Mn oxides have developed at the surface on Devonian carbonates ( $\mathrm{Li}$ et al. 2007), while in India $\mathrm{Mn}$ oxides have developed in laterites due to chemical weathering of the underlying Cretaceous Deccan basalts (Beauvais et al. 2016; Bonnet et al. 2014, 2016). In both instances the ${ }^{40} \mathrm{Ar} /{ }^{39} \mathrm{Ar}$ ages for Mn oxides are all younger Cenozoic, indicative of the chemical weathering at the current landscape surface.

In Australia the Permian Mt. Leyshon epithermal gold deposit and its surrounding hydrothermal alteration reach close to the present land surface from where chemical weathering has penetrated down to produce supergene alunite-jarosite group minerals in the host rocks and ore (Scott 1990). K-Ar ages of these supergene minerals are late Cenozoic, similar to ${ }^{40} \mathrm{Ar} /{ }^{39} \mathrm{Ar}$ ages for Mn oxides in the current weathering profile in a nearby part of Australia (Feng and Vasconcelos 2007). Similarly, in Spain the late Paleozoic Las Cruces volcanogenic massive sulfide deposit was exhumed and affected by subaerial oxidation connected to the current landscape (Tornos et al. 2017). ${ }^{40} \mathrm{Ar} /{ }^{39} \mathrm{Ar}$ dating of supergene alunite yielded 
various Cenozoic ages, consistent with ${ }^{40} \mathrm{Ar} /{ }^{39} \mathrm{Ar}$ ages of supergene alunite and jarosite associated with the weathering of other similar ore deposits within the Iberian Pyrite Belt.

These results are exactly as anticipated if weathering started after the retreating Flood waters had exhumed much of the current landscape. It is to be expected there would be a range of ages for the formation of supergene minerals, as some would start forming where weathering commenced as the Flood ended, and then further supergene minerals would form later in the early postFlood decades in areas that experienced residual catastrophism and erosion which delayed the onset of weathering. Thus, the retreating Flood waters would have rapidly eroded off the overburden covering many primary ore deposits, and then as the Flood ended the supergene weathering began. Subsequently, it would have required the extended time in the decades after the Flood for the chemical reactions to produce these supergene minerals from their primary precursors.

The relative ages of formation of all these supergene minerals thus date the beginning of weathering reaching the level where the precursor primary ore minerals occur, but erosion and weathering would have started well before that date. So, in the context of the Flood, as the waters retreated erosion occurred and then weathering could have begun while Noah was still on the Ark. However, there would have been insufficient time in the closing weeks of the Flood for chemical weathering to have generated large enough quantities of supergene minerals for dating. Thus, if the Flood/post-Flood boundary is placed at the K-Pg boundary in the geologic record (a relative date of $66 \mathrm{Ma}$ ) (Austin et al. 1994; Whitmore and Garner 2008), then it is not unexpected that only a few of these relative ages for supergene mineral formation would slightly pre-date that boundary (the $>66$ Ma dates in Fig. 1).

Much caution obviously needs to be exercised in interpreting all these data. Nevertheless, this is a line of investigation that could still potentially yield some demarcation of where the Flood/postFlood boundary should be placed in the geologic record. Thus, these relative ages of formation of supergene minerals from endFlood and post-Flood weathering appear to be consistent with a Flood/post-flood boundary low in the Cenozoic, likely as low as the K-Pg boundary many Flood geologists prefer based on many other criteria (Austin et al 1994; Snelling 2009; Whitmore and Garner 2008; Whitmore and Wise 2008).

\section{CONCLUSIONS}

The radioisotope dating methods cannot produce absolute ages because of the demonstrated violations of the three assumptions foundational to them. Nevertheless, because many sources of error are systematic, these methods can still produce relative ages, that may then be useful in determining where rocks and minerals fit in the geologic record. It has also been shown that the so-called geological column is likely a reasonable representation of the geologic record of earth history, especially as the global extent of some fossil-bearing sedimentary layers and the megasequences that contain them are powerful evidence of the global Flood cataclysm as described in the Genesis account. Those who dispute the integrity and usefulness of this geologic record use minor exceptions to disparage this "big picture" Flood evidence, and fail to propose an alternative coherent Flood model consistent with the physical rock record.

When the Flood waters retreated after likely peaking on Day 150 , major erosion occurred. By Day 314 the Genesis account says the face of the ground had dried, but Noah waited another 57 days before God instructed him and his cargo to leave the Ark. The ground surface may have been dry, but extra time was needed to allow the water table to drop, soil to form and plants to grow. Thus, the weathering front started to progress downwards, a process that would have been a major shaper of the land surface and topography in the early post-Flood era, in which it required decades for the chemical weathering reactions to produce the supergene minerals.

Primary ore deposits were formed at depth before and during the Flood, but the erosion by the retreating Flood waters stripped away enough of the cover rocks for weathering of their tops to commence after the Flood ended and for supergene minerals to start forming post-Flood. Subsequent residual post-Flood catastrophism may have involved mountains still rising and ore deposits still forming, such as the porphyry copper deposits associated with granite intrusions as the Andes continued to rise. The erosion to expose those later-formed ore deposits and the subsequent weathering to produce supergene minerals from them may thus have occurred well into the early post-Flood era.

The supergene iron oxides, and potassium-bearing sulfates and manganese oxides, produced by weathering of ore deposits can be radioisotope dated to yield the relative ages of their formation. The relative ages obtained span the whole Cenozoic, indicative of progressive weathering and initiation of supergene mineral formation through the Cenozoic. Thus, it is proposed that the relative dates for the first formation of supergene minerals can be used as a helpful criterion for determining the placement of the Flood/post-Flood boundary in the geologic record.

The relative ages of supergene minerals thus favor a placement at the K-Pg boundary with a relative age of $66 \mathrm{Ma}$, the Flood/ post-Flood boundary favored by many Flood geologists. The few slightly earlier relative ages likely resulted from weathering that commenced before Noah stepped off the Ark to end the Flood event, while the spread of relative ages through the Cenozoic represents the progressive formation of supergene minerals as primary ore deposits emplaced during, and some maybe after, the Flood were subsequently exposed to weathering by residual catastrophism. Continuing investigation of this criterion for placement of the Flood/post-Flood boundary seems warranted.

\section{ACKNOWLEDGMENT}

Two anonymous reviewers are thanked for their critical comments and suggestions which resulted in this paper being greatly improved.

\section{REFERENCES}

Alpers, C.N., and G.H. Brimhall. 1988. Middle Miocene climatic change in the Atacama Desert, northern Chile: Evidence from supergene mineralization at La Escondida. Geological Society of America Bulletin 100:1640-1656.

Anderson, L.A., Jr. 2014. Waves of opinion: The chronology of the Flood in literature past and present. In Grappling with the chronology of the Genesis Flood: Navigating the flow of time in biblical narrative, eds. 
S.W. Boyd, and A.A. Snelling, pp.189-230. Green Forest, Arkansas: Master Books.

Arancibia, G., S.J. Matthews, and C. Pérez de Arce. 2006. K-Ar and ${ }^{40} \mathrm{Ar} /{ }^{39} \mathrm{Ar}$ geochronology of supergene processes in the Atacama Desert, northern Chile: Tectonic and climatic relations. Journal of the Geological Society, London 163:107-118.

Austin, S. A. 1998. The declining power of post-Flood volcanoes. Acts \& Facts 27, no.8 (August):i-iv.

Austin, S.A., J.R. Baumgardner, D.R. Humphreys, A.A. Snelling, L. Vardiman, and K.P. Wise. 1994. Catastrophic plate tectonics: A global Flood model of earth history. In Proceedings of the Third International Conference on Creationism, ed. R.E. Walsh, pp.609-612. Pittsburgh, Pennsylvania: Creation Science Fellowship.

Baumgardner, J.R. 2012. Do radioisotope methods yield trustworthy relative ages for the earth's rocks? Journal of Creation 26, no.3:68-75.

Beauvais, A., G. Ruffet, O. Hénocque, and F. Colin. 2008. Chemical and physical erosion rhythms of the West African Cenozoic morphogenesis: The ${ }^{39} \mathrm{Ar}-{ }^{40} \mathrm{Ar}$ dating of supergene K-Mn oxides. Journal of Geophysical Research Earth Surface 113:F04007, doi:10.1029/2008JF000996.

Beauvais, A., N.J. Bonnet, D. Chardon, N. Arnaud, and M. Jayananda. 2016. Very long-term stability of passive margin escarpment constrained by ${ }^{40} \mathrm{Ar} /{ }^{39} \mathrm{Ar}$ dating on K-Mn oxides. Geology 44:299-302.

Bonnet, N.J., A. Beauvais, N. Arnaud, N. Chardon, and M. Jayananda. 2014. First ${ }^{40} \mathrm{Ar} /{ }^{39} \mathrm{Ar}$ dating of intense late Palaeogene lateritic weathering in Peninsular India. Earth and Planetary Science Letters 386:126-137.

Bonnet, N.J., A. Beauvais, N. Arnaud, N. Chardon, and M. Jayananda. 2016. Cenozoic lateritic weathering and erosion history of Peninsular India from ${ }^{40} \mathrm{Ar} /{ }^{39} \mathrm{Ar}$ dating of supergene K-Mn oxides. Chemical Geology 446:33-53.

Černý, P., P.L. Blevin, M. Cuney, and D. London. 2005. Granite-related ore deposits. In Economic geology: One hundredth anniversary volume, eds. J.W. Hedenquist, J.F.H. Thompson, R.J. Goldfarb, and J.P. Richards, pp. 337-370. Littleton, Colorado: Society of Economic Geologists.

Clarey, T.L. 2015a. The Whopper Sand. Acts \& Facts 44, no.3 (March):14.

Clarey, T.L. 2015b. Grappling with megasequences. Acts \& Facts 44, no.4 (April):18-19.

Clarey, T.L. 2015c. Reading African strata. Acts \& Facts 44, no.9 (September):9.

Clarey, T.L. 2016. The Ice Age as a mechanism for post-Flood dispersal. Journal of Creation 30, no.2:54-59.

Clarey, T.L. 2017. South America shows the Flood progression. Acts \& Facts 46, no.3 (March):9.

Clout, J.M.F., and B.M. Simonson. 2005. Precambrian iron formations and iron formation-hosted iron ore deposits. In Economic geology: One hundredth anniversary volume, eds. J.W. Hedenquist, J.F.H. Thompson, R.J. Goldfarb, and J.P. Richards, pp. 643-679. Littleton, Colorado: Society of Economic Geologists.

Colin, F., A. Beauvais, G. Ruffet, and O. Hénocque. 2005. First ${ }^{40} \mathrm{Ar} /{ }^{39} \mathrm{Ar}$ geochronology of lateritic manganiferous pisolites: Implications for the Palaeogene history of a West African landscape. Earth and Planetary Science Letters 238:172-188.

Dammer, D., I. McDougall, and A.R. Chivas. 1999. Timing of weatheringinduced alteration of manganese deposits in Western Australia: Evidence from $\mathrm{K} / \mathrm{Ar}$ and ${ }^{40} \mathrm{Ar} /{ }^{39} \mathrm{Ar}$ dating. Economic Geology 94, no.1:87-108.

de Oliveira Carmo, I., and P.M. Vasconcelos. 2006. ${ }^{40} \mathrm{Ar} /{ }^{39} \mathrm{Ar}$ geochronology constraints on Late Miocene weathering rates in Minas Gerais, Brazil. Earth and Planetary Science Letters 241:80-94.

De Putter, T., G. Ruffet, J, Yans, and F. Mees. 2015. The age of supergene manganese deposits in Katanga and its implications for the Neogene evolution of the African Great Lakes Region. Ore Geology Reviews 71:350-362.

Deng, X.-D., J.-W. Li. P.M. Vasconcelos, B.E. Cohen, and T.M. Kusky. 2014. Geochronology of the Baye Mn oxide deposit, southern Yunnan Plateau: Implications for the late Miocene to Pleistocene paleoclimatic conditions and topographic evolution. Geochimica et Cosmochimica Acta 139:227-247.

Dill, H.G. 2015. Supergene alteration of ore deposits: From nature to humans. Elements 11, no. 5:311-316.

Faure, G., and T.M. Mensing. 2005. Isotopes: Principles and applications, 3rd ed. Hoboken, New Jersey: John Wiley \& Sons, Inc.

Feng, Y.-X., and P.M. Vasconcelos. 2007. Chronology of Pleistocene weathering processes, southeast Queensland, Australia. Earth and Planetary Science Letters 263:275-287.

Franklin, J.M., H.L. Gibson, I.R. Jonasson, and G.A. Galley. 2005. Volcanogenic massive sulfide deposits. In Economic geology: One hundredth anniversary volume, eds. J.W. Hedenquist, J.F.H. Thompson, R.J. Goldfarb, and J.P. Richards, pp. 523-560. Littleton, Colorado: Society of Economic Geologists.

Freyssinet, Ph., C.R.M. Butt, R.C. Morris, and P. Piantone. 2005. Oreforming processes related to lateritic weathering. In Economic geology: One hundredth anniversary volume, eds. J.W. Hedenquist, J.F.H. Thompson, R.J. Goldfarb, and J.P. Richards, pp. 681-722. Littleton, Colorado: Society of Economic Geologists.

Goldfarb, R.J., T. Baker, B. Dubé, D.I. Groves, C.J.R. Hart, and P. Gosselin. 2005. Distribution, character, and genesis of gold deposits in metamorphic terranes. In Economic geology: One hundredth anniversary volume, eds. J.W. Hedenquist, J.F.H. Thompson, R.J. Goldfarb, and J.P. Richards, pp. 407-450. Littleton, Colorado: Society of Economic Geologists.

Gradstein, F.M., J.G. Ogg, M.D. Schmitz, and G.M. Ogg, eds. 2012. The geologic time scale 2012, 2 vols. Amsterdam, The Netherlands: Elsevier.

Gutzmer, J., A.P. Du Plooy, and N.J. Beukes. 2012. Timing of supergene enrichment of low-grade sedimentary ores in the Kalahari Manganese Field, South Africa. Ore Geology Reviews 47:136-153.

Hautmann, S., and H.J. Lippholt. 2000. ${ }^{40} \mathrm{Ar} /{ }^{39} \mathrm{Ar}$ dating of central European K-Mn oxides - A chronological framework of supergene alteration processes during the Neogene. Chemical Geology 170:37-80.

Heim, J.A., P.M. Vasconcelos, D.L. Shuster, K.A. Farley, and G.C. Broadbent. 2006. Dating palaeochannel iron ore by (U-Th)/He analysis of supergene goethite, Hamersley Province, Australia. Geology 34:173176.

Holt, R.D. 1996. Evidence for a late Cainozoic Flood/post-Flood boundary. Creation Ex Nihilo Technical Journal 10, no.1:128-167.

Leach, D.L., D.F. Sangster, K.D. Kelley, R.R. Large, G. Garven, C.R. Allen, J. Gutzmer, and S. Walters. 2005. Sediment-hosted lead-zinc deposits: A global perspective. In Economic geology: One hundredth anniversary volume, eds. J.W. Hedenquist, J.F.H. Thompson, R.J. Goldfarb, and J.P. Richards, pp. 561-607. Littleton, Colorado: Society of Economic Geologists.

Li, J.-W., and P.M. Vasconcelos. 2002. Cenozoic continental weathering and its implications for the palaeoclimate: Evidence from ${ }^{40} \mathrm{Ar} /{ }^{39} \mathrm{Ar}$ geochronology of supergene $\mathrm{K}-\mathrm{Mn}$ oxides in Mt Tabor, central 
Queensland, Australia. Earth and Planetary Science Letters 200:223239.

Li, J.-W., P.M. Vasconcelos, N. Duzgoren-Aydin, D.-R. Yan, W. Zhang, X.-D. Deng, X.-F. Zhao, Z.-P. Zeng, and M.-A. Hu. 2007. Neogene weathering and supergene manganese enrichment in subtropical South China: $\mathrm{An}{ }^{40} \mathrm{Ar} /{ }^{39} \mathrm{Ar}$ approach and paleoclimatic significance. Earth and Planetary Science Letters 256:389-402.

Lippolt, H.J., T. Brander, and N.R. Mankopf. 1998. An attempt to determine formation age of goethites and limonites by $(\mathrm{U}+\mathrm{Th})-{ }^{4} \mathrm{He}$ dating. Neues Jahrbuch für Mineralogie - Monatshefte 11:505-528.

Miller, H.B.D., P.M. Vasconcelos, J.M. Eiler, and K.A. Farley. 2017. A Cenozoic terrestrial paleoclimate record from He dating and stable isotope geochemistry of goethites from Western Australia. Geology 45, no. 10:895-898.

Monteiro, H.S., P.M. Vasconcelos, K.A. Farley, C.A. Spier, and C.L. Mello. 2014. (U-Th)/He geochronology of goethite and the origin and evolution of cangas. Geochimica et Cosmochimica Acta 131:267-289.

Morton, G.R. 1984. Global, continental and regional sedimentation systems and their implications. Creation Research Society Quarterly 21:23-33.

Mote, T.I., T.A. Becker, P. Renne, and G.H. Brimhall. 2001. Chronology of exotic mineralization at El Salvador, Chile, by ${ }^{40} \mathrm{Ar} /{ }^{39} \mathrm{Ar}$ dating of copper wad and supergene alunite. Economic Geology 96:351-366.

Neuendorf, K.K.E., J.P. Mehl, Jr., and J.A. Jackson, eds. 2005. Glossary of geology, 5th ed. Alexandria, Virginia: American Geological Institute.

Oard, M.J. 2004. Pediments formed by the Flood: Evidence for the Flood/ post-Flood boundary in the Late Cenozoic. Journal of Creation 18, no. $2: 15-27$.

Oard, M.J. 2007. Defining the Flood/post-Flood boundary in sedimentary rocks. Journal of Creation 21, no.1:98-110.

Oard, M.J. 2010a. The geological column is a general Flood order with many exceptions. Journal of Creation 24, no.2:78-82.

Oard, M.J. 2010b. Is the K/T the post-Flood boundary? - Part 1: Introduction and the scale of sedimentary rocks. Journal of Creation 24, no.2:95-104.

Oard, M.J. 2010c. Is the K/T the post-Flood boundary? - Part 2: Paleoclimates and fossils. Journal of Creation 24, no.3:87-93.

Oard, M.J. 2011. Is the K/T the post-Flood boundary? - Part 3: Volcanism and plate tectonics. Journal of Creation 25, no.1:57-62.

Oard, M.J. 2013a. Geology indicates the terrestrial Flood/post-Flood boundary is mostly in the Late Cenozoic. Journal of Creation 27, no.1:119-127.

Oard, M.J. 2013b. The Flood/post-Flood boundary. Journal of Creation 27 , no. 2:44-45.

Reed, J.K. and Oard, M.J., eds. 2006. The geologic column: Perspectives within diluvial geology. Chino Valley, Arizona: Creation Research Society.

Reich, M., C. Palacios, G. Vargas, S. Luo, E.M. Cameron, M.I. Leybourne, M.A. Parada, A. Zúñiga, and C.-F. You. 2009. Supergene enrichment of copper deposits since the onset of modern hyperaridity in the Atacama Desert, Chile. Mineralium Deposita 44:497-504.

Reich, M., and P.M. Vasconcelos. 2015. Geological and economic significance of supergene metal deposits. Elements 11, no. 5:305-310.

Ross, M.R. 2012. Evaluating potential post-Flood boundaries with biostratigraphy - The Pliocene/Pleistocene boundary. Journal of
Creation 26, no.2:82-87.

Ross, M.R. 2014a. Improving our understanding of creation and its history. Journal of Creation 28, no.2:62-63.

Ross, M.R. 2014b. Reliable data disconfirm a late Cenozoic post-Flood boundary. Journal of Creation 28 no.2:66-68.

Scott, K.M. 1990. Origin of alunite- and jarosite-group minerals in the Mt. Leyshon epithermal gold deposit, northeast Queensland, Australia. American Mineralogist 75:1176-1181.

Seedorff, E., J.H. Dilles, J.M. Proffett, Jr., M.T. Einaudi, L. Zurcher, W.J.A. Stavast, D.A. Johnson, and M.D. Barton. 2005. Porphyry deposits: Characteristics and origin of hypogene features. In Economic geology: One hundredth anniversary volume, eds. J.W. Hedenquist, J.F.H. Thompson, R.J. Goldfarb, and J.P. Richards, pp. 251-298. Littleton, Colorado: Society of Economic Geologists.

Shuster, D.L., P.M. Vasconcelos, J.A. Heim, and K.A. Farley. 2005. Weathering geochronology by (U-Th)/He dating of goethite. Geochimica et Cosmochimica Acta 69:659-673.

Sillitoe, R.H. 2005. Supergene oxidized and enriched porphyry copper and related deposits. In Economic geology: One hundredth anniversary volume, eds. J.W. Hedenquist, J.F.H. Thompson, R.J. Goldfarb, and J.P. Richards, pp. 723-768. Littleton, Colorado, Society of Economic Geologists.

Sillitoe, R.H., and E.H. McKee. 1996. Age of supergene oxidation and enrichment in the Chilean porphyry copper province. Economic Geology 91, no. 1: 164-179.

Simmons, S.F., N.C. White, and D.A. John. 2005. Geological characteristics of epithermal precious and base metal deposits. In Economic geology: One hundredth anniversary volume, eds. J.W. Hedenquist, J.F.H. Thompson, R.J. Goldfarb, and J.P. Richards, pp. 485-522. Littleton, Colorado: Society of Economic Geologists.

Snelling, A.A. 2000. Geochemical processes in the mantle and crust. In Radioisotopes and the age of the earth: A young-earth creationist research initiative, eds. L. Vardiman, A.A. Snelling, and E.F. Chaffin, pp.123-304. El Cajon, California: Institute for Creation Research; St. Joseph, Missouri: Creation Research Society.

Snelling, A.A. 2008. Transcontinental rock layers. Answers 3, no.3 (JulySeptember):80-83.

Snelling, A.A. 2009. Earth's catastrophic past: Geology, creation and the Flood. Dallas, Texas: Institute for Creation Research.

Snelling, A.A. 2010. Radiometric dating: Making sense of the patterns. Answers 5, no.1 (January-March):72-75.

Snelling, A.A. 2014a. Geological issues: Charting a scheme for correlating the rock layers with the biblical record. In Grappling with the chronology of the Genesis Flood: Navigating the flow of time in biblical narrative, eds. S.W. Boyd, and A.A. Snelling, pp.77-109. Green Forest, Arkansas: Master Books.

Snelling, A.A. 2014b. Geophysical issues: Understanding the origin of the continents, their rock layers and mountains. In Grappling with the chronology of the Genesis Flood: Navigating the flow of time in biblical narrative, eds. S.W. Boyd, and A.A. Snelling, pp.111-143. Green Forest, Arkansas: Master Books.

Snelling, A.A. 2014c. Paleontological issues: Deciphering the fossil record of the Flood and its aftermath. In Grappling with the chronology of the Genesis Flood: Navigating the flow of time in biblical narrative, eds. S.W. Boyd, and A.A. Snelling, pp.145-185. Green Forest, Arkansas: Master Books.

Snelling, A.A. 2015. Sifting through layers of meaning. Answers 10, no.4 
(October-December):30-36

Snelling, A.A. 2016a. Determination of the radioisotope decay constants and half-lives: Potassium-40 $\left({ }^{40} \mathrm{~K}\right)$. Answers Research Journal 9:171196.

Snelling, A.A. 2016b. Chalk it up to a global Flood. Answers 11, no.3 (July-September):32-35.

Snelling, A.A. 2017a. Determination of the decay constants and half-lives of uranium-238 $\left({ }^{238} \mathrm{U}\right)$ and uranium-235 $\left({ }^{235} \mathrm{U}\right)$, and the implications for $\mathrm{U}-\mathrm{Pb}$ and $\mathrm{Pb}-\mathrm{Pb}$ radioisotope dating methodologies. Answers Research Journal 10:1-38.

Snelling, A.A. 2017b. Five mass extinctions or one cataclysmic event? Answers 12, no.2 (March-April):64-70.

Spier, C.A., P.M. Vasconcelos, and S.M.B. Oliviera. 2006. ${ }^{40} \mathrm{Ar} /{ }^{39} \mathrm{Ar}$ geochronological constraints on the evolution of lateritic iron deposits in the Quadrilátero Ferrífero, Minas Gerais, Brazil. Chemical Geology 234:79-104.

Tornos, F., F. Velasco, J.F. Slack, A. Delgado, N. Gomez-Miguelez, J. M. Escobar, and C. Gomez. 2017. The high-grade Las Cruces copper deposit, Spain: A product of secondary enrichment in an evolving basin. Mineralium Deposita 52:1-34.

Tyler, D.J., and H.G. Coffin. 2006. Accept the column, reject the chronology. In The geologic column: Perspectives within diluvial geology, eds. J.K. Reed, and M.J. Oard, pp.53-69. Chino Valley, Arizona: Creation Research Society.

Vardiman, L. 2003. Hypercanes following the Genesis Flood. In Proceedings of the Fifth International Conference on Creationism, ed. R. L. Ivey, Jr., pp. 17-28. Pittsburgh, Pennsylvania: Creation Science Fellowship.

Vardiman, L. 2012. Tracking those incredible hypercanes. Acts \& Facts 41, no.5 (May):12-14.

Vardiman, L., A.A. Snelling, and E.F. Chaffin, eds. 2005. Radioisotopes and the age of the earth: Results of a young-earth research initiative, vol. 2. El Cajon, California: Institute for Creation Research; Chino Valley, Arizona: Creation Research Society.

Vasconcelos, P.M. 1999a. K-Ar and ${ }^{40} \mathrm{Ar} /{ }^{39} \mathrm{Ar}$ geochronology of weathering processes. Annual Review of Earth and Planetary Sciences 27:183-229.

Vasconcelos, P.M. 1999b. ${ }^{40} \mathrm{Ar} /{ }^{39} \mathrm{Ar}$ geochronology of supergene processes in ore deposits. Reviews in Economic Geology 12:73-113.

Vasconcelos, P.M. 2002. Geochronology of weathering in the Mt Isa and Charters Towers regions, northern Queensland. Cooperative Research Centre for Landscape Evolution and Mineral Exploration, Report 139.

Vasconcelos, P.M., J.A. Heim, K.A. Farley, H. Monteiro, and K. Waltenberg. 2013. ${ }^{40} \mathrm{Ar} /{ }^{39} \mathrm{Ar}$ and $(\mathrm{U}-\mathrm{Th}) / \mathrm{He}-{ }^{4} \mathrm{He} /{ }^{3} \mathrm{He}$ chronology of landscape evolution and channel iron deposit genesis at Lynn Peak, Western Australia. Geochimica et Cosmochimica Acta 117:283-312.

Vasconcelos, P.M., M. Reich, and D.L. Shuster. 2015. The paleoclimatic signatures of supergene metal deposits. Elements 11, no. 5:317-322.

Walker, T. 2014a. Post-Flood boundary - a robust analysis flawed by hidden assumptions. Journal of Creation 28, no.2:60-61.

Walker, T. 2014b. Research needed to resolve questions with late Cenozoic post-Flood boundary. Journal of Creation 28, no.2:63-66.

Whitmore, J.H. 2013. The potential for and implications of widespread post-Flood erosion and mass wasting processes. In Proceedings of the Seventh International Conference on Creationism, ed. M.F. Horstemeyer. Pittsburgh, Pennsylvania: Creation Science Fellowship.

Whitmore, J.H., and P. Garner. 2008. Using suites of criteria to recognize pre-Flood, Flood, and post-Flood strata in the rock record with application to Wyoming (USA). In Proceedings of the Sixth International Conference on Creationism, ed. A.A. Snelling, pp.425-448. Pittsburgh, Pennsylvania: Creation Science Fellowship; Dallas, Texas: Institute for Creation Research.

Whitmore, J.H., and K.P. Wise. 2008. Rapid and early post-Flood mammalian diversification evidenced in the Green River Formation. In Proceedings of the Sixth International Conference on Creationism, ed. A.A. Snelling, pp.449-457. Pittsburgh, Pennsylvania: Creation Science Fellowship; Dallas, Texas: Institute for Creation Research.

Williams, P.J., M.D. Barton, D.A. Johnson, L. Fontboté, A. de Haller, G. Mark, N.H.S. Oliver, and R. Marschik. 2005. Iron oxide copper-gold deposits: Geology, space-time distribution, and possible modes of origin. In Economic geology: One hundredth anniversary volume, eds. J.W. Hedenquist, J.F.H. Thompson, R.J. Goldfarb, and J.P. Richards, pp. 371-405. Littleton, Colorado: Society of Economic Geologists.

Yapp, C.J. 1991. Oxygen isotopes in an oolitic limestone and the determination of goethite $\delta^{18} \mathrm{O}$ values by selective impurities: The 5M $\mathrm{NaOH}$ method. Geochimica et Cosmochimica Acta 55:4194-4215.

\section{THE AUTHOR}

Andrew has a BSc (Hons.) in geology from the University of NSW and $\mathrm{PhD}$ in geology from the University of Sydney, both in Sydney, Australia. He worked for six years in the mineral exploration and mining industry in Australia. Since late 1983 he has worked fulltime in creation ministry, with the Creation Science Foundation in Australia (15 years), then the Institute for Creation Research (9 years), and since mid-2007 as Director of Research for Answers in Genesis. He has authored numerous research papers and served as a technical editor of research journals and books.

\section{APPENDIX}




\section{Supergene Weathering of Ore Deposits \\ 1. Iron Oxides}

The oxidation of magnetite $\left(\mathrm{Fe}_{3} \mathrm{O}_{4}\right)$ to hematite $\left(\mathrm{Fe}_{2} \mathrm{O}_{3}\right)$ and the hydration of magnetite or hematite to goethite $(\mathrm{FeOOH})$ are the product of chemical reactions (identifiable through ore microscopy) within supergene blankets overlying lateritic iron deposits. These chemical reactions are illustrated and labeled with blue numbered arrows in the Eh-pH diagram in Fig. 2 representing the thermodynamically favored pathways, and are:

Reaction (1)

$$
2 \mathrm{Fe}_{3} \mathrm{O}_{4 \text { (magnetite) }}+1 / 2 \mathrm{O}_{2 \text { (dissolved) }} \leftrightarrow 3 \mathrm{Fe}_{2} \mathrm{O}_{3 \text { (hematite) }}
$$

Reaction (2)

$$
\mathrm{Fe}_{2} \mathrm{O}_{3 \text { (hematite) }}+\mathrm{H}_{2} \mathrm{O}_{\text {(liquid) }} \leftrightarrow 2 \mathrm{FeOOH} \text { (goethite) }
$$

As reaction (1) indicates, the direct oxidation of magnetite to hematite is thermodynamically favored $\left(\Delta \mathrm{G}^{0}\right.$ reaction $=-49.375$ kcal) when rocks, which formed under reducing conditions, enter the oxidation zone near the earth's surface. This process can be dated by the (U-Th)/He analysis of supergene hematite. On the other hand, the direct hydration of supergene hematite (martite) to goethite (reaction 2$)$ is not thermodynamically favored $\left(\Delta \mathrm{G}^{0}\right.$ reaction $=+0.567 \mathrm{kcal})$. Yet, goethite formed after hematite is abundant in duricrusts overlying supergene iron deposits. It appears that the hydration of the primary ore oxides involves a two-stage process involving reactions thermodynamically favorable in the supergene zone of ore deposits. First, hematite is reductively dissolved to soluble $\mathrm{Fe}^{2+}$ by carboxylic acids (for example, acetic acid, a common organic acid in weathering profiles) $\left(\Delta \mathrm{G}^{0}\right.$ reaction $=-96.99 \mathrm{kcal})$ :

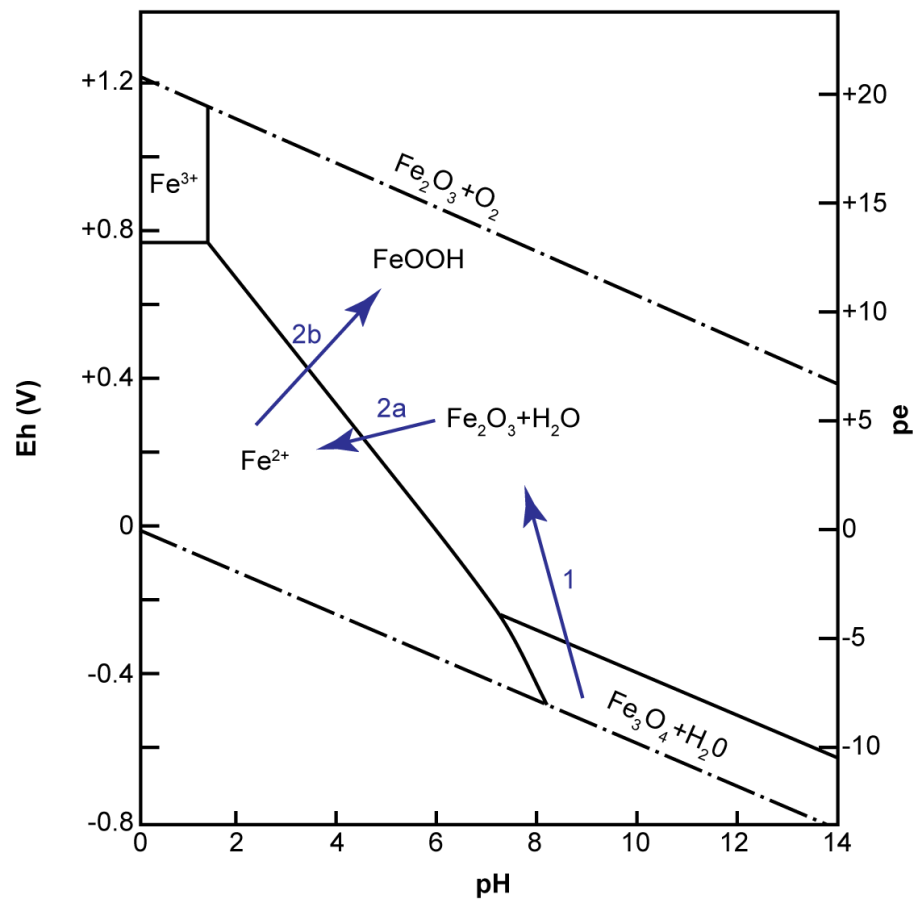

Figure 2. Eh- $\mathrm{pH}$ diagram for the $\mathrm{Fe}-\mathrm{O}_{2}-\mathrm{H}_{2} \mathrm{O}$ system. Blue arrows illustrate the thermodynamically favored pathways for the oxidation (1), dissolution (2a), and precipitation $(2 \mathrm{~b})$ reactions.
Reaction (2a)

$$
\begin{aligned}
& 4 \mathrm{Fe}_{2} \mathrm{O}_{3 \text { (hematite) }}+\mathrm{CH}_{3} \mathrm{COOH} \\
& 8 \mathrm{Fe}^{2+} \text { (aquueous) } \\
& +2 \mathrm{CO}_{2 \text { (dissolved) }}+10 \mathrm{H}_{2} \mathrm{O} \text { (iliquid) }
\end{aligned}
$$

This is followed by the subsequent re-oxidation of $\mathrm{Fe}^{2+}$ by dissolved $\mathrm{O}_{2}$ in weathering solutions and precipitation of goethite $\left(\Delta \mathrm{G}^{0}\right.$ reaction $\left.=-104.286 \mathrm{kcal}\right)$ :

\section{Reaction (2b)}

$$
\begin{aligned}
& 2 \mathrm{Fe}^{2+}{ }_{\text {(aqueous) }}+1 / 2 \mathrm{O}_{2 \text { (dissolved) }}+4 \mathrm{OH}^{-}{ }_{\text {(aqueous) }} \leftrightarrow \\
& 2 \mathrm{FeOOH}_{\text {(goethite) }}+\mathrm{H}_{2} \mathrm{O}_{\text {(liquid) }}
\end{aligned}
$$

These reaction pathways are shown as labeled blue arrows in Fig. 2. Microscopic evidence also suggests close links between these reactions and microorganisms (Monteiro et al. 2014).

\section{Supergene Copper Minerals}

Supergene metal deposits contribute significantly to the world's supply of selected base metals $(\mathrm{Cu}, \mathrm{Zn}, \mathrm{Ni}, \mathrm{Co})$ and structural metals ( $\mathrm{Al}, \mathrm{Fe}, \mathrm{Ni}, \mathrm{V})$. Giant porphyry copper deposits contribute about $70 \%$ of the total global copper inventory and have median grades at $\sim 0.4 \mathrm{wt} \% \mathrm{Cu}$ (with hypogene and supergene $\mathrm{Cu}$ grades often being reported together). Yet supergene grades in most deposits are higher than hypogene grades.

In most porphyry copper orebodies, the stepwise hydrolysis and oxidation of primary pyrite-bearing assemblages leads to a decrease in the $\mathrm{pH}$ of descending groundwaters and the liberation of oxidized sulfur as $\mathrm{SO}_{4}^{2-}$ anions. There is a simultaneous breakdown of chalcopyrite $\left(\mathrm{CuFeS}_{2}\right)$, which produces soluble $\mathrm{Cu}^{2+}$ ions that are transported downwards, encountering progressively greater reducing conditions deep into the profile. This process is accompanied by "capping," the precipitation of iron oxyhydroxides in the leached zone from which $\mathrm{Cu}$ is removed. The thickness of the leached cap is highly variable but can reach several hundred meters in porphyry copper deposits, particularly when the water table was deep enough during the supergene oxidation and enrichment phase (Reich and Vasconcelos 2015).

Copper is concentrated within the subjacent oxide zone, which forms laterally extensive deposits composed of assemblages called "green oxides" or "copper oxides". This mineralogically and compositionally complex layer is composed of copper minerals including oxides, sulfates, hydroxy-chlorides, carbonates, silicates, and native copper. Among the copper minerals that may be encountered are cuprite $\left(\mathrm{Cu}_{2} \mathrm{O}\right)$, tenorite $(\mathrm{CuO})$, brochantite $\left[\mathrm{Cu}_{4} \mathrm{SO}_{4}(\mathrm{OH})_{6}\right]$, chalcanthite $\left[\mathrm{CuSO}_{4} \cdot 5 \mathrm{H}_{2} \mathrm{O}\right]$, antlerite $\left[\mathrm{Cu}_{3} \mathrm{SO}_{4}(\mathrm{OH})_{4}\right]$, malachite $\left[\mathrm{Cu}_{2} \mathrm{CO}_{3}(\mathrm{OH})_{2}\right]$, azurite $\left[\mathrm{Cu}_{3}\left(\mathrm{CO}_{3}\right)_{2}(\mathrm{OH})_{2}\right]$, atacamite $\left[\mathrm{Cu}_{2} \mathrm{Cl}(\mathrm{OH})_{3}\right]$, turquoise $\left[\mathrm{CuAl}_{6}\left(\mathrm{PO}_{4}\right)_{4}(\mathrm{OH})_{8} \cdot 4 \mathrm{H}_{2} \mathrm{O}\right]$, native copper $\left(\mathrm{Cu}^{0}\right)$, and chrysocolla $\left(\mathrm{Cu}_{2-\mathrm{x}} \mathrm{Al}_{\mathrm{x}}\right) \mathrm{H}_{2-\mathrm{x}} \mathrm{Si}_{2} \mathrm{O}_{5}(\mathrm{OH})_{4} \cdot \mathrm{nH}_{2} \mathrm{O}$, among many others.

The precipitation of "green oxide" mineral assemblages in the vadose zone is largely controlled by the enclosing rock type and $\mathrm{pH}$ (Fig. 3), forming thick $(<200-300 \mathrm{~m}$ ) layers containing ore with $>1 \mathrm{wt} \% \mathrm{Cu}$ grade. Furthermore, $\mathrm{Cu}$ and other metals dissolved in groundwater can migrate laterally when hydraulic conditions are favorable and form large "exotic-type" Cu-oxide deposits in gravel sequences that are far (distal) from the source.

Under more reducing conditions, the remaining $\mathrm{Cu}$ in the 


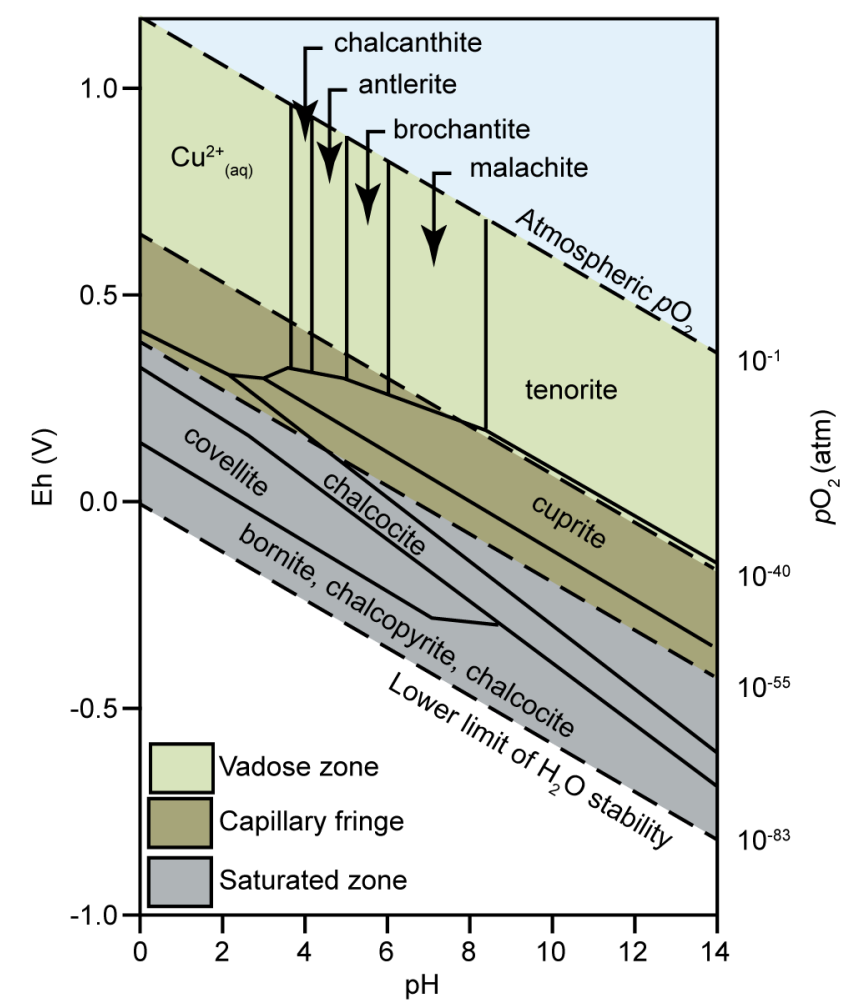

Figure 3. Graph of redox (Eh) and the partial oxygen pressure $\left(p \mathrm{O}_{2}\right)$ versus $\mathrm{pH}$ showing the stability of dissolved copper species and copper minerals in the supergene environment (after Sillitoe 2005). The diagram maps out possible occurrence of stable phases under particular redox and $\mathrm{pH}$ conditions along a supergene profile. Conditions shift vertically from the more reducing, saturated zone in gray at the bottom (below the water table), to the more oxidizing conditions towards the top of the profile (vadose zone, where the soil and rock pores contain air as well as water).

descending metal- and sulfate-rich solutions will form secondary sulfides in the saturated zone below the water table where free oxygen is almost absent ( $p \mathrm{O}_{2} \sim$ below 10-40 atm.) (see Fig. 3). Formation of secondary sulfides occurs by replacement of $\mathrm{Fe}$ by $\mathrm{Cu}$ in the hypogene sulfides [pyrite $\left(\mathrm{FeS}_{2}\right)$, chalcopyrite $\left(\mathrm{CuFeS}_{2}\right)$, and bornite $\left.\left(\mathrm{Cu}_{5} \mathrm{FeS}_{4}\right)\right]$. The secondary chalcocite $\left(\mathrm{Cu}_{2} \mathrm{~S}\right)$ occurs on top, where $\mathrm{Cu}^{2+} / \mathrm{HS}^{-}$is high, while covellite $(\mathrm{CuS})$ precipitates below, where $\mathrm{Cu}^{2+} / \mathrm{HS}^{-}$is lower. Enriched $\mathrm{Cu}$ sulfide zones in porphyry copper deposits are usually tens to hundreds of meters thick and can contain more than 1.5 gigatons of ore with $0.4-1.7$ $\mathrm{wt} \% \mathrm{Cu}$, invariably reaching higher $\mathrm{Cu}$ grades than those found in the primary (hypogene) orebodies (Reich and Vasconcelos 2015).

\section{Supergene Potassium-Bearing Minerals}

Alunite $\left[\mathrm{KAl}_{3}\left(\mathrm{SO}_{4}\right)_{2}(\mathrm{OH})_{6}\right]$ and jarosite $\left[\mathrm{KFe}_{3}^{3+}(\mathrm{OH})_{6}\left(\mathrm{SO}_{4}\right)_{2}\right]$ are present in weathering profiles encompassing a large range of geological environments. They are common in the oxidation zones of ore deposits, paleosols, silcretes, cave deposits, and weathered river or marine terraces, or deltaic deposits (Vasconcelos 1999a). Supergene alunite and jarosite commonly occur intergrown with primary and other supergene minerals in the weathered zones of orebodies, and as precipitates in veins and cavities (Alpers and Brimhall 1998; Sillitoe and McKee 1996).

The most important parameters controlling the distribution of alunite-jarosite in natural environments are $\mathrm{pH}, \mathrm{Eh},\left(\mathrm{SO}_{4}^{2-}\right),\left(\mathrm{K}^{+}\right)$, $\left(\mathrm{Fe}^{3+}\right),\left(\mathrm{Al}^{3+}\right)$ [where the symbol ( ) denotes activity of the aqueous species], $\mathrm{H}_{2} \mathrm{O}$ fugacity, and temperature. In alunite-jarosite systems the chemical reactions which are dated by the K-Ar or ${ }^{40} \mathrm{Ar} /{ }^{39} \mathrm{Ar}$ methods are the simple precipitation of jarosite or alunite from aqueous solution (equations 1 and 4 in Table 1) or more complex mineral transformations (equations 2, 3, 5, 6, and 7 in Table 1).

During weathering processes, manganese is mobile as the cation $\mathrm{Mn}^{2+}$, which predominates for most of the range of conditions characteristic of natural-water systems (Vasconcelos 1999a). At $\mathrm{pH}>10.5$, the complex $\mathrm{MnOH}^{+}$becomes the predominant form, and in solutions with high concentrations of $\mathrm{HCO}_{3}^{-}$and $\mathrm{SO}_{4}^{2-}$ the complexes $\mathrm{MnHCO}_{3}^{+}$and $\mathrm{MnSO}_{4}$ (aqueous) may be important. Organic acids also control manganese solubility in the surficial environment. $\mathrm{Mn}^{3+}$ species may occur in strongly acid or organicrich solutions. However, the tendency for the $\mathrm{Mn}^{3+}$ species to disproportionate indicates that it does not play a major role in the solution chemistry of manganese under surface conditions.

The chemical oxidation of $\mathrm{Mn}^{2+}$ and $\mathrm{Mn}^{3+}$ and the disproportionation of $\mathrm{Mn}^{3+}$ in aerated surface water lead to the precipitation of $\mathrm{Mn}^{4+}$ oxides. These oxides further catalyze the oxidation process. Thus, Mn oxide precipitation tends to occur on previously deposited oxides, forming accretionary growth bands. Supergene Mn oxides also catalyze the precipitation of other cations from solution ( $\mathrm{Bi}, \mathrm{Ni}, \mathrm{Co}, \mathrm{Cu}, \mathrm{K}, \mathrm{Pb}$, and more), leading to the formation of complex supergene phases (Vasconcelos 1999a). Hollandite [Ba, $\left.\mathrm{K}\left(\mathrm{Mn}_{6}^{4+}{ }_{6} \mathrm{Mn}^{3+}{ }_{2}\right) \mathrm{O}_{16}\right]$, coronadite, cryptomelane, birnessite, romanéchite, todorokite, and vernalize are some of the complex Mn oxides commonly found in soils and weathering profiles.

Similar to jarosite-alunite systems, the K-Ar or ${ }^{40} \mathrm{Ar} /{ }^{39} \mathrm{Ar}$ dating of supergene Mn oxides may determine the direct precipitation of these oxides from aqueous solutions (equation 8 in Table 1) or determine the timing of more complex metasomatic reactions in the weathering environment (equations 9, 10, and 11 in Table 1). When multiple precipitation-dissolution-reprecipitation reactions occur, geochronology of supergene Mn oxides may date the influx of solutions, promoting the dissolution of the previously precipitated $\mathrm{Mn}$ oxides, the transport of aqueous $\mathrm{Mn}^{2+}$ elsewhere in the system, and the reprecipitation of new generations of Mn oxides in suitable sites. Because the most significant aqueous manganese species in the surficial environment is $\mathrm{Mn}^{2+}$, the partial dissolution of previously precipitated Mn oxides implies the influx of acid and/or reducing solutions (equations 12, 13 and 14 in Table 1).

The aqueous $\mathrm{Mn}^{2+}$ species generated by reactions 12, 13 and 14 (Table 1) must be reprecipitated nearby within the weathering profile if these reactions are to be identified and dated. The kinetics of the oxidation of $\mathrm{Mn}^{2+}$ aqueous species and the precipitation of $\mathrm{Mn}^{4+}$ oxides is generally slow in neutral to slightly acidic oxygenated weathering solutions. In alkaline conditions $(\mathrm{pH}>8)$ these reactions proceed more rapidly. The reactions are also catalyzed by bacteria and by mineral surfaces in the natural environment. The identification of the exact reaction controlling the precipitation of datable Mn oxides is desirable if the ages obtained are to be used to interpret paleoclimatic conditions. 
Table 1. Representative reactions illustrating the precipitation of supergene K-bearing Mn sulfates and oxides in weathering profiles of ore deposits (after Vasconcelos 1999a, b).

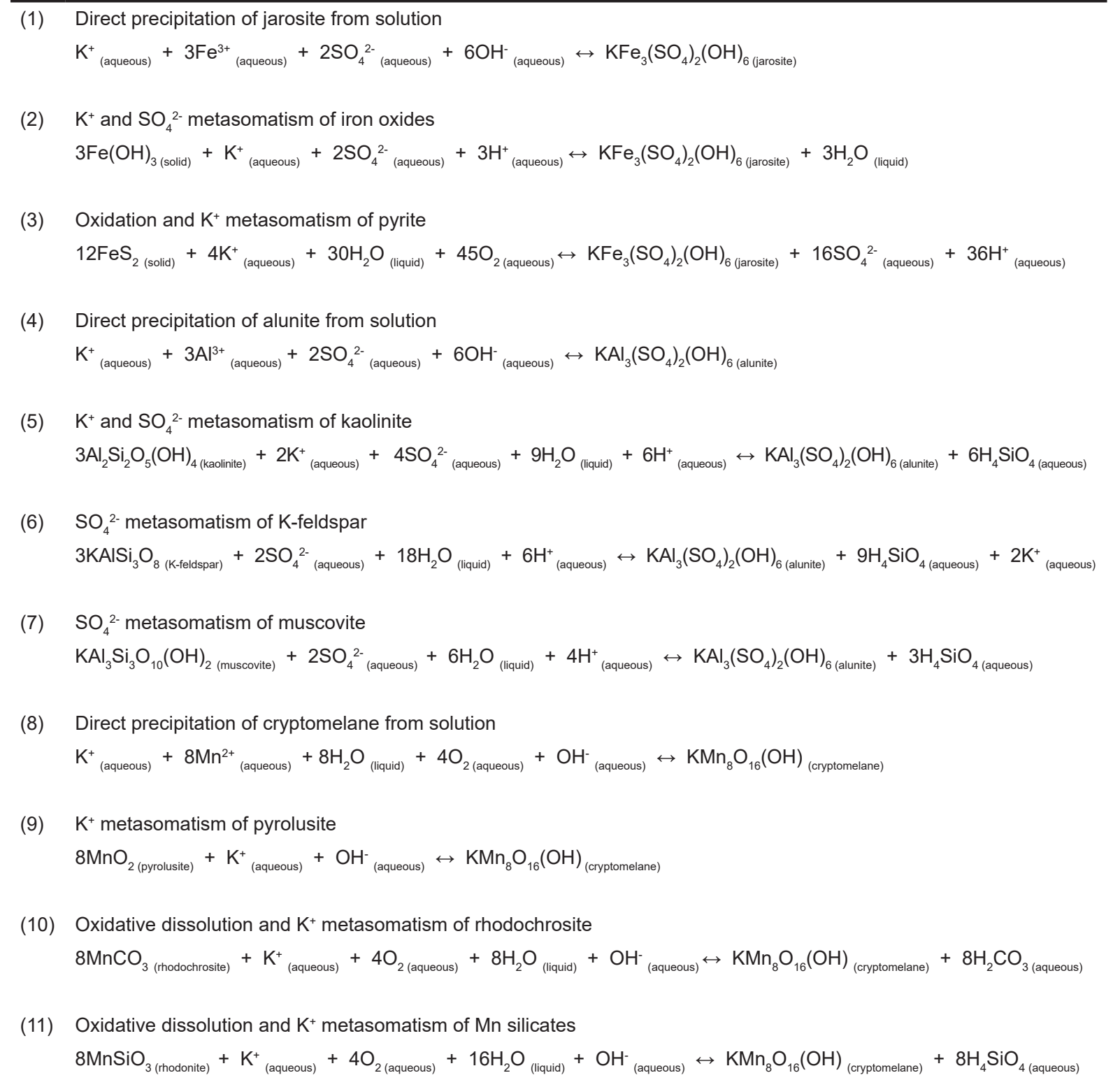

(12) Reductive dissolution by acidification, followed by direct precipitation of cryptomelane from solution $\mathrm{KMn}_{8} \mathrm{O}_{16}(\mathrm{OH})_{\text {(cryptomelane) }}+16 \mathrm{H}^{+}$(aqueous) $\leftrightarrow \mathrm{K}^{+}{ }_{\text {(aqueous) }}+8 \mathrm{Mn}^{2+}{ }_{\text {(aqueous) }}+8 \mathrm{H}_{2} \mathrm{O}_{\text {(liquid) }}+4 \mathrm{O}_{2 \text { (aqueous) }}+\mathrm{OH}_{\text {(aqueous) }}$

(13) Reductive dissolution by organic ligands, followed by direct precipitation of cryptomelane from solution $\mathrm{KMn}_{8} \mathrm{O}_{16}(\mathrm{OH})_{\text {(cryptomelane) }}+8 \mathrm{CH}_{2} \mathrm{O}_{\text {(aqueous) }}+4 \mathrm{O}_{2 \text { (aqueous) }} \leftrightarrow \mathrm{K}^{+}$(aqueous) $+8 \mathrm{Mn}^{2+}{ }_{\text {(aqueous) }}+8 \mathrm{HCO}_{3}^{-}$(aqueous) $+9 \mathrm{OH}^{-}$(aqueous)

(14) Reductive dissolution by soluble $\mathrm{Fe}^{2+}$, followed by direct precipitation of cryptomelane from solution $\mathrm{KMn}_{8} \mathrm{O}_{16}(\mathrm{OH})_{\text {(cryptomelane) }}+31 \mathrm{H}_{2} \mathrm{O}_{\text {(liquid) }}+16 \mathrm{Fe}^{2+}{ }_{\text {(aqueous) }} \leftrightarrow 16 \mathrm{Fe}(\mathrm{OH})_{3 \text { (ferrihydrite) }}+\mathrm{K}_{\text {(aqueous) }}^{+}+8 \mathrm{Mn}^{2+}{ }_{\text {(aqueous) }}+15 \mathrm{H}^{+}{ }_{\text {(aqueous) }}$ 